$\underline{\text { Research article }}$

\title{
Preliminary survey on knowledge, attitudes and practices regarding rabies
}

\author{
JT Muthunuwan ${ }^{1}$, AGKH Ganhewa ${ }^{1}$, HDSG Perera ${ }^{1}$, \\ M Hishaam $^{1}$, WMMS Bandara ${ }^{1}$, HAKM Gunasekera ${ }^{2}$ \\ Sri Lankan Journal of Infectious Diseases 2017 Vol.7 (1):38-46 \\ DOI: http://doi.org/http://doi.org/10.4038/sljid.v7i1.8133
}

\begin{abstract}
Introduction: The Ministry of Health's goal is to reduce the number of human deaths from rabies to zero by 2020. Community awareness and responsible behaviour of pet owners are key factors to achieve this goal. Knowledge, attitude and practices (KAP) regarding rabies has been reported only from the Kandy district. We describe a preliminary survey among outpatients in Colombo, to supplement existing knowledge.
\end{abstract}

Methods: A convenience sample $(n=200)$ was selected from $26^{\text {th }}$ March to $8^{\text {th }}$ April 2016, from outpatients of the National Hospital of Sri Lanka. Data was collected using a selfadministered questionnaire.

Results: The majority were females (66.5\%), Buddhist $(80.5 \%)$ and from the Colombo District $(58.5 \%)$. More than $75 \%$ of the subjects knew that dogs were the main reservoir of rabies, transmission was by biting, that washing the wound was important and that rabies could be prevented by vaccinating dogs and humans. However, only $22.5 \%$ were aware that rabies was fatal after development of disease. There was a lack of knowledge regarding other animal reservoirs, other modes of transmission and clinical features of rabid animals.

Pet owners were more likely to have been bitten by a dog than those who did not own pets $(\mathrm{p}<0.05)$. However, only half of the respondents admitted that their pets had been vaccinated during the last year.

Conclusion: Future health educational programs should highlight the risks of rabies transmission by animals other than dogs and methods of transmission other than bites as well as the clinical features of rabies for easy identification of rabid animals. The message that vaccination after developing the disease does not change the outcome needs to be clearly presented. Reasons for non compliance of dog vaccination needs to be investigated and rectified.

Keywords: Rabies, Sri Lanka, Knowledge

\footnotetext{
${ }^{1}$ Kotelawala Defence University, Ratmalana

${ }^{2}$ Faculty of Medical Sciences, University of Sri Jayewardenepura

Address for correspondence: Dr. HAKM Gunasekera, Faculty of Medical Sciences, University of Sri Jayewardenepura, Gangodawila, Nugegoda ; Telephone: +94 718329772 ; Email: kamani.lk@gmail.com 


\section{Introduction}

Rabies is a fatal animal disease of significant public health importance globally. ${ }^{1}$ Although it is a vaccine preventable disease, it is responsible for tens of thousands of deaths annually, mostly in Asia and Africa. ${ }^{1}$ Domestic and wild animals are reservoirs for rabies. ${ }^{2}$ Exposures recorded in Sri Lanka are mainly from domestic or stray animals with very little exposure from wild animals. ${ }^{2}$ Therefore, elimination of rabies in the domestic and stray animal population would lead to a marked decline in the number of cases in Sri Lanka.

The policy goal of the Ministry of Health, Sri Lanka is to reduce the number of human deaths from rabies to zero by $2020 .^{3}$ This appears feasible as only five cases of human rabies were recorded in the first half of 2016 compared with 24 in all of 2015. ${ }^{3}$ In 2015, the Colombo district had the second highest recorded number of deaths (4 deaths) due to rabies. ${ }^{4}$

Community awareness of rabies and responsible behaviour of pet owners are key components for prevention. Studies on this subject have been conducted in the Kandy district in $2006 .{ }^{5}$ However, these findings do not necessarily apply to other districts in the country. The current study was therefore designed to ascertain the knowledge, attitudes and practices of a sample population attending the outpatient department at the National Hospital of Sri Lanka (NHSL) in order to identify areas that need to be addressed through future health educational programs.

\section{Methods}

A preliminary survey was conducted from $26^{\text {th }}$ March to $8^{\text {th }}$ April 2016 among outpatients attending the NHSL. A pre-tested self-administered structured questionnaire was used to collect data from 200 respondents. Every fifth patient was selected to be part of the survey. Those over 12 years of age were recruited following informed written consent. For those who were illiterate, the questionnaire was read out and the responses given marked by the data collector.

The questionnaire was formulated in a similar structure to the previously reported survey in Kandy, to enable comparison. ${ }^{5}$ Chi square test or Fisher's exact test (2 tailed) was used as appropriate to evaluate statistical differences in responses between pet owners and non-pet owners and those who had been previously bitten. A p value $<0.05$ was considered as significant.

\section{Results}

Outpatient attendees resident in the Colombo district consisted of 58.5\% of the sample. Ages ranged from 12-76 years (median age 36 years) and $66.5 \%$ were females. The majority were Buddhists $(80.5 \%)$ and Sinhalese $(88.5 \%)$. Fifty six percent were educated up to the GCE Ordinary Level. Sixty-four percent of our convenience sample were pet owners (Table 1). 
Table 1 Profile of study respondents $(n=200)$

\begin{tabular}{|c|c|c|c|}
\hline \multirow{2}{*}{ Hometown } & \multicolumn{2}{|r|}{ n } & $\%$ \\
\hline & Colombo & 117 & 58.5 \\
\hline 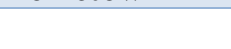 & Not Colombo & 83 & 41.5 \\
\hline \multirow[t]{2}{*}{ Gender } & Male & 67 & 33.5 \\
\hline & Female & 133 & 66.5 \\
\hline \multirow[t]{6}{*}{ Age (years) } & $12-19$ & 18 & 9.0 \\
\hline & $20-29$ & 63 & 31.5 \\
\hline & $20-39$ & 31 & 15.5 \\
\hline & $40-49$ & 22 & 11.0 \\
\hline & $50-59$ & 41 & 20.5 \\
\hline & $\geq 60$ & 25 & 12.0 \\
\hline \multirow[t]{2}{*}{$\begin{array}{l}\text { Educational } \\
\text { status }\end{array}$} & $\begin{array}{l}\text { Up to GCE } \\
\text { O/Levels }\end{array}$ & 112 & 56 \\
\hline & $\begin{array}{l}\text { Higher than } \\
\text { GCE O/Levels }\end{array}$ & 88 & 44 \\
\hline \multirow[t]{4}{*}{ Religion } & Buddhism & 161 & 80.5 \\
\hline & Hinduism & 6 & 3.0 \\
\hline & Islam & 8 & 4.0 \\
\hline & Christianity & 25 & 12.5 \\
\hline \multirow[t]{4}{*}{ Ethnicity } & Sinhalese & 177 & 88.5 \\
\hline & Tamil & 13 & 6.5 \\
\hline & Muslim & 8 & 4.0 \\
\hline & Burgher & 2 & 1.0 \\
\hline \multirow[t]{2}{*}{ Pet ownership } & With pets & 128 & 64.0 \\
\hline & Without pets & 72 & 36.0 \\
\hline
\end{tabular}

(Table 2).
More than $75 \%$ of our convenience sample knew that dogs were the main animal reservoir, were aware that rabies was transmitted through bite wounds and that washing the bite wound was an important first aid measure (Table 2). They were also aware that rabies could be prevented by vaccination of dogs and post exposure vaccination of humans and that vaccines were available free of charge from government centres. The majority of study participants had gained this information from health care officials (Table 2).

Knowledge was lacking regarding other animals that could transmit rabies and modes of transmission other than bites (Table 2). Foaming was identified as a sign of rabies but knowledge of other signs, especially of the paralytic type was lacking in most participants (Table 2). Only $22.5 \%$ were aware that rabies could not be cured once humans develop the disease

There was no difference in gender, hometown or knowledge of rabies between those who had or had not previously experienced a dog bite ( $p>0.05)$ except for two instances (Table 3$)$. There was a higher level of awareness that cats could also be a reservoir of infection in those who had been previously bitten by dogs $(\mathrm{p}<0.05)$. Most of those with no previous exposure to bites, correctly answered the question on prevention of dog rabies by vaccination $(\mathrm{p}<0.05)$.

\section{Attitudes}

Most considered rabies a major problem and stray dogs a nuisance (Table 4). The majority (94\%) were willing to take post exposure treatment if bitten by an animal (Table 4). However, most people were not willing to kill their pets if suspected of having rabies (Table 4). A large group of participants (40.5\%) had no knowledge of stray dog control (Table 4). A few (19\%) suggested the use of dog pounds, killing of strays $(17.5 \%)$, vaccination $(14 \%)$ and sterilization of dogs $(9 \%)$ as measures for controlling the stray dog population. On direct questioning, 78\% were in favour of sterilization of dogs as a control measure (Table 4).

\section{Practices}

Most participants (97\%) responded that they would seek treatment from a doctor or hospital after exposure and that they would go immediately following an exposure (Table 4). Most pet owners had dogs (Table 4) and pet owners were more likely to have been bitten by a dog than those who didn't have pets $(\mathrm{p}<0.05)$ (Table 5). Only half the respondents admitted that their pets had been vaccinated during the past year (Table 4). However, those who had been 
previously bitten were more likely to have had their pet dogs vaccinated during the previous year $(\mathrm{p}<0.05)($ Table 5$)$.

Table 2 Knowledge of rabies in study participants $(n=200)$

\begin{tabular}{|c|c|c|c|}
\hline \multicolumn{2}{|l|}{ Question asked } & No & $\%$ \\
\hline \multirow{6}{*}{$\begin{array}{l}\text { Animal reservoirs of rabies } \\
\text { in Sri Lanka }\end{array}$} & Dog & 198 & 99.0 \\
\hline & Cat & 90 & 45.0 \\
\hline & Rat & 38 & 19.0 \\
\hline & Bat & 33 & 16.5 \\
\hline & Cattle & 16 & 8.0 \\
\hline & Squirrels & 27 & 13.5 \\
\hline \multirow{5}{*}{$\begin{array}{l}\text { Symptoms and signs of } \\
\text { rabies in dogs }\end{array}$} & Biting without provocation & 110 & 55.0 \\
\hline & Agitated behaviour & 116 & 58.0 \\
\hline & Growling & 63 & 31.5 \\
\hline & Foaming at the mouth & 142 & 71.0 \\
\hline & Refusal of food & 44 & 22.0 \\
\hline \multirow{3}{*}{$\begin{array}{l}\text { Can rabies be cured after } \\
\text { symptoms and signs } \\
\text { appear? }\end{array}$} & Yes & 89 & 44.5 \\
\hline & No & 51 & 25.5 \\
\hline & Uncertain & 60 & 30.0 \\
\hline \multirow{3}{*}{$\begin{array}{l}\text { Methods of transmission of } \\
\text { rabies }\end{array}$} & Biting & 196 & 98.0 \\
\hline & Scratches & 113 & 56.5 \\
\hline & Licking of open wound & 110 & 55.0 \\
\hline \multirow{3}{*}{$\begin{array}{l}\text { Can human rabies be } \\
\text { prevented by vaccination? }\end{array}$} & Yes & 153 & 76.5 \\
\hline & No & 11 & 5.5 \\
\hline & Uncertain & 36 & 18.0 \\
\hline \multirow{3}{*}{$\begin{array}{l}\text { Can vaccination of dogs } \\
\text { prevent rabies? }\end{array}$} & Yes & 186 & 93.0 \\
\hline & No & 6 & 3.0 \\
\hline & Uncertain & 8 & 4.0 \\
\hline \multirow{3}{*}{$\begin{array}{l}\text { Can dog rabies vaccine be } \\
\text { obtained from authorized } \\
\text { government veterinary } \\
\text { offices? }\end{array}$} & Yes & 169 & 84.5 \\
\hline & No & 8 & 4.0 \\
\hline & Uncertain & 23 & 11.5 \\
\hline \multirow{5}{*}{$\begin{array}{l}\text { The following procedure } \\
\text { should be adopted after a } \\
\text { dog bite }\end{array}$} & $\begin{array}{l}\text { Wash the wound with soap } \\
\text { and water }\end{array}$ & 181 & 90.5 \\
\hline & Application of ointments & 13 & 6.5 \\
\hline & $\begin{array}{l}\text { Clean the wound with } \\
\text { surgical spirit or betadine }\end{array}$ & 44 & 22.0 \\
\hline & Apply dressing & 65 & 32.5 \\
\hline & $\begin{array}{l}\text { Take patient to a hospital } \\
\text { immediately }\end{array}$ & 123 & 61.5 \\
\hline \multirow[t]{5}{*}{ Sources of information } & Health officials & 150 & 75.0 \\
\hline & Television & 103 & 51.5 \\
\hline & Newspaper & 69 & 34.5 \\
\hline & Radio & 48 & 24.0 \\
\hline & Internet & 49 & 24.5 \\
\hline
\end{tabular}


Table 3. Association between knowledge and previous exposure to dog bite

\begin{tabular}{|c|c|c|c|c|}
\hline & & Bitten & $\begin{array}{l}\text { Never } \\
\text { bitten }\end{array}$ & p value \\
\hline \multirow[t]{2}{*}{ Gender } & Male & 26 & 41 & 0.488 \\
\hline & Female & 45 & 88 & \\
\hline \multirow[t]{2}{*}{ Hometown } & Within Colombo district & 43 & 74 & 0.660 \\
\hline & Outside Colombo district & 28 & 55 & \\
\hline \multirow[t]{9}{*}{ Methods of transmission of rabies } & Biting & & & \\
\hline & Correct & 70 & 126 & $1.0^{*}$ \\
\hline & Incorrect & 01 & 03 & \\
\hline & Licking of open wound & & & \\
\hline & Correct & 41 & 69 & 0.562 \\
\hline & Incorrect & 30 & 60 & \\
\hline & Scratches & & & \\
\hline & Correct & 40 & 73 & 0.973 \\
\hline & Incorrect & 31 & 56 & \\
\hline \multirow{18}{*}{$\begin{array}{l}\text { Animal reservoir of rabies in Sri } \\
\text { Lanka }\end{array}$} & Dogs & & & \\
\hline & Correct & 69 & 129 & $0.125^{*}$ \\
\hline & Incorrect & 02 & 00 & \\
\hline & Cats & & & \\
\hline & Correct & 39 & 51 & 0.036 \\
\hline & Incorrect & 32 & 78 & \\
\hline & Rats $^{\dagger}$ & & & \\
\hline & Correct & 57 & 105 & 0.848 \\
\hline & Incorrect & 14 & 24 & \\
\hline & Bats & & & \\
\hline & Correct & 15 & 18 & 0.191 \\
\hline & Incorrect & 56 & 111 & \\
\hline & Cattle & & & \\
\hline & Correct & 8 & 8 & 0.206 \\
\hline & Incorrect & 63 & 121 & \\
\hline & Squirrels & & & \\
\hline & Correct & 11 & 16 & 0.541 \\
\hline & Incorrect & 60 & 113 & \\
\hline \multirow[t]{15}{*}{$\begin{array}{l}\text { Symptoms and signs of rabies in } \\
\text { dogs }\end{array}$} & $\begin{array}{l}\text { Biting without } \\
\text { provocation }\end{array}$ & & & \\
\hline & Correct & 43 & 67 & 0.241 \\
\hline & Incorrect & 28 & 62 & \\
\hline & Agitated behaviour & & & \\
\hline & Correct & 43 & 73 & 0.586 \\
\hline & Incorrect & 28 & 56 & \\
\hline & Growling & & & \\
\hline & Correct & 23 & 40 & 0.840 \\
\hline & Incorrect & 48 & 89 & \\
\hline & Foaming at the mouth & & & \\
\hline & Correct & 55 & 87 & 0.135 \\
\hline & Incorrect & 16 & 42 & \\
\hline & Refusal of food & & & \\
\hline & Correct & 17 & 27 & 0.623 \\
\hline & Incorrect & 54 & 102 & \\
\hline
\end{tabular}


Table 3 (ct). Association between knowledge and previous exposure to dog bite

\begin{tabular}{|c|c|c|c|c|}
\hline & & Bitten & $\begin{array}{l}\text { Never } \\
\text { bitten }\end{array}$ & p value \\
\hline \multirow[t]{15}{*}{$\begin{array}{l}\text { The following procedure should be } \\
\text { adopted after a dog bite }\end{array}$} & $\begin{array}{l}\text { Wash with soap and } \\
\text { water }\end{array}$ & & & \\
\hline & Correct & 63 & 118 & 0.527 \\
\hline & Incorrect & 08 & 11 & \\
\hline & Application of ointments & & & \\
\hline & Correct & 67 & 120 & $1.0^{*}$ \\
\hline & Incorrect & 04 & 09 & \\
\hline & $\begin{array}{l}\text { Clean the wound with } \\
\text { surgical spirit or betadine }\end{array}$ & & & \\
\hline & Correct & 11 & 33 & 0.099 \\
\hline & Incorrect & 60 & 96 & \\
\hline & Apply dressing & & & \\
\hline & Correct & 24 & 41 & 0.770 \\
\hline & Incorrect & 47 & 88 & \\
\hline & $\begin{array}{l}\text { Take patient to hospital } \\
\text { immediately }\end{array}$ & & & \\
\hline & Correct & 46 & 77 & 0.478 \\
\hline & Incorrect & 25 & 52 & \\
\hline \multirow{2}{*}{$\begin{array}{l}\text { Immediate medical attention to be } \\
\text { sought following a dog bite }\end{array}$} & Yes & 69 & 127 & $0.616^{*}$ \\
\hline & No & 02 & 02 & \\
\hline \multirow{2}{*}{$\begin{array}{l}\text { Can dog rabies vaccine be obtained } \\
\text { from authorized government } \\
\text { veterinary offices? }\end{array}$} & Yes & 60 & 109 & 0.998 \\
\hline & No / unsure & 11 & 20 & \\
\hline \multirow{2}{*}{$\begin{array}{l}\text { Can vaccination of } \mathrm{dogs} \\
\text { prevent rabies? }\end{array}$} & Yes & 62 & 124 & $0.03^{*}$ \\
\hline & No & 09 & 05 & \\
\hline \multirow{2}{*}{$\begin{array}{l}\text { Can human rabies be prevented by } \\
\text { vaccination? }\end{array}$} & Yes & 58 & 95 & 0.438 \\
\hline & No & 13 & 34 & \\
\hline \multirow{2}{*}{$\begin{array}{l}\text { Can rabies be cured after } \\
\text { symptoms and signs appear? }\end{array}$} & No & 23 & 28 & 0.097 \\
\hline & Yes / unsure & 48 & 101 & \\
\hline
\end{tabular}

"Fisher's exact test

$\dagger$ Rat rabies has not been reported in Sri Lanka. Therefore, those who said NO were taken as correct 
Table 4 Attitudes and practices of study participants

\begin{tabular}{|c|c|c|c|}
\hline \multirow{4}{*}{$\begin{array}{l}\text { Following a dog bite how soon } \\
\text { would you seek medical advice? }\end{array}$} & & $\mathbf{n}$ & $\%$ \\
\hline & Immediately & 196 & 98.0 \\
\hline & Within a week & 2 & 1.0 \\
\hline & Within a month & 2 & 1.0 \\
\hline \multirow[t]{3}{*}{$\begin{array}{l}\text { Following a dog bite from whom } \\
\text { would you seek treatment }\end{array}$} & $\begin{array}{l}\text { Nearest doctor or } \\
\text { hospital }\end{array}$ & 194 & 97.0 \\
\hline & $\begin{array}{l}\text { Native/ traditional } \\
\text { healers }\end{array}$ & 4 & 2.0 \\
\hline & No one & 2 & 1.0 \\
\hline \multirow{2}{*}{$\begin{array}{l}\text { Are you willing to take the } \\
\text { recommended treatment for } \\
\text { prevention of rabies }\end{array}$} & Yes & 188 & 94.0 \\
\hline & No & 12 & 6.0 \\
\hline \multirow[t]{4}{*}{ Type of pet } & Dog & 100 & 50.0 \\
\hline & Cat & 22 & 11.0 \\
\hline & Other & 6 & 3.0 \\
\hline & No pet & 72 & 36.0 \\
\hline \multirow{3}{*}{$\begin{array}{l}\text { Vaccination status of pet dog } \\
\text { during the last } 1 \text { year }\end{array}$} & Yes & 102 & 51.0 \\
\hline & No & 26 & 13.0 \\
\hline & No pets & 72 & 36.0 \\
\hline \multirow{2}{*}{$\begin{array}{l}\text { Would you euthanize your pet if } \\
\text { found rabid }\end{array}$} & Yes & 92 & 46.0 \\
\hline & No & 108 & 54.0 \\
\hline \multirow{2}{*}{ Annoyed with stray dogs } & Yes & 132 & 66.0 \\
\hline & No & 68 & 34.0 \\
\hline \multirow{4}{*}{$\begin{array}{l}\text { Actions suggested for } \\
\text { controlling stray dog } \\
\text { population }\end{array}$} & Killing & 35 & 17.5 \\
\hline & Sterilization & 18 & 9.0 \\
\hline & $\begin{array}{l}\text { Segregate in a dog } \\
\text { pound }\end{array}$ & 38 & 19.0 \\
\hline & Uncertain & 109 & 54.5 \\
\hline \multirow[t]{2}{*}{ In favour of animal sterilization } & Yes & 156 & 78.0 \\
\hline & No & 44 & 22.0 \\
\hline
\end{tabular}

Table 5 Variables associated with previous history of being bitten

\begin{tabular}{|c|c|c|c|}
\hline & $\begin{array}{l}\text { Previously } \\
\text { bitten }\end{array}$ & $\begin{array}{c}\text { Not } \\
\text { bitten }\end{array}$ & p value \\
\hline Pet owner & 54 & 68 & 0.001 \\
\hline Non pet owner & 17 & 61 & \\
\hline $\begin{array}{l}\text { Vaccinated dog within the last } \\
1 \text { year }\end{array}$ & 49 & 53 & 0.001 \\
\hline Not vaccinated & 6 & 20 & \\
\hline No pets & 16 & 56 & \\
\hline
\end{tabular}

\section{Discussion}

Most participants identified dogs as the source of rabies, as shown in this study, as well as the previous survey in Kandy. It is important that future campaigns should focus more on improving knowledge of other animal reservoirs and clinical features of rabid animals, especially of the paralytic type.

The majority of participants knew that post exposure vaccination could prevent rabies. However, it was disturbing to note that $44.5 \%$ of respondents believed that rabies could be 
cured once symptoms developed and 30\% were unsure of the outcome of human rabies. The previous study in Kandy ${ }^{5}$ reported a high level of awareness of the fatal nature of rabies, but it is not clear how the question was phrased in that survey. ${ }^{5}$ In our questionnaire, we did not ask "Is rabies fatal?" Our question was phrased as "can you be cured after developing symptoms and signs of rabies". Future surveys should include questions to find out if respondents clearly understand the need for seeking treatment without delay and that the vaccine is for prevention and not as a cure.

Knowledge and attitudes of the use of post exposure vaccination was satisfactory in the current study. Vaccination and sterilization of dogs are key strategies to control rabies in the stray dog population. However, a small group of respondents (17.5\%) still considered killing of dogs as a suitable strategy. People need to be made aware that more humane measures are equally effective and that responsible pet ownership is the most important factor.

Although many were aware that vaccination of dogs could prevent rabies, only half admitted that they had vaccinated their pet during the previous year. The survey done in Kandy showed a similar pattern. ${ }^{5}$ As shown in our study, pet owners are more likely to be bitten. The fact that pet owners are most likely to require post exposure vaccination needs to be conveyed to the public, in order to encourage people to vaccinate their pet animals. Reasons for non-compliance with dog vaccination need to be studied, and corrective measures should be taken in future mass dog vaccination campaigns.

More detailed questions on attitudes and practices regarding responsible pet ownership need to be included in future surveys. More information is needed on the reasons for dogs being allowed to roam freely on roads, willingness of owners to sterilize pets and what they would do with unwanted puppies. The media should be utilized to a greater extent for educating the public and making them aware about dog adoption agencies.

\section{Ethical considerations}

Approval was obtained from the Ethics Review Committee of the Faculty of Medicine, Kotelawala Defence University (EC-11-121). Administrative approval was obtained from all relevant authorities.

\section{Acknowledgements}

We thank the patients for consenting to be part of this study. We are grateful to the Director, National Hospital of Sri Lanka for permission to carry out the study.

\section{Conflicts of interests}

No conflicts of interests

\section{References}

1. World Health Organisation. Rabies 2017. http://www.who.int/rabies/vaccines_and_RIG/en/

2. Kularatne SAM, Ralapanawa DMPUK, Weerakoon K, et al. Pattern of animal bites and post exposure prophylaxis in rabies: A five year study in a tertiary care unit in Sri Lanka. BMC Infect Dis. 2016; 16:62. doi : 10.1186/s12879-016-1394-5 
3. Harischandra PAL, Gunesekera A, Janakan N, et al. Sri Lanka takes action towards a target of zero rabies death by 2020. WHO South-East Asia Journal of Public Health. 2016; 5(2):113-16. No doi

4. Rabies statistical bulletin 2015. Colombo: Public Health Veterinary Services; 2015 http://www.rabies.gov.lk/download/Stasistics\%20\%202015.pdf, accessed 27 January 2017.

5. Matibag GC, Kamigaki T, Kumarasiri PVR, et al. Knowledge, attitudes and practices survey of rabies in a community in Sri Lanka. Environ Health Prev Med. 2007; 12:84-9. doi : 10.1007/BF02898154 